The source of Peter Martyr's information was undoubtedly Columbus himself, for we find the same fishing incident related, together with a more trustworthy description of a species of sucking-fish (probably Echeneis naucrates), in those fragments of the Journal of the second voyage of the great discoverer which have been preserved by his son Ferdinand, and by the chroniclers Bartolomé de Las Casas and Fray Andrés Bernádez.

Bernáldez, curate of Los Palocios, was a personal friend of Columbus, and had access to his Journals and other papers. Thirteen chapters of his history are devoted to the Admiral and his discoveries. In chapter 126 occurs an interesting passage relating to the Remora, which no doubt faithfully reproduces the famous navigator's own words. The only naturalist of modern times who has commented upon the incident in question, so far as the present writer has been able to find, is Alexander. von Humboldt. Poey briefly refers to it in his description of the socalled Echeneis guaican, and Dr. Günther appears to doubt that the Remora was actually employed in the capacity narrated.

The passage in Bernáldez reads :-

"[At the Queen's Gardens, off the coast of Cuba]

each of which was three codos long, to the ships of the Admiral; and there they gave some account of these islands, and of their cacique, who was close at hand, and had sent them to hunt. They asked the Admiral to go on shore, and they would make for them a great feast, and would give to them all four of the turtles." C. R. Eastman.

American Museum of Natural History, New York.

\title{
A Mathematical Paradox.
}

"Two horses, side by side and four feet apart, run once round a race track. How much further does the outer horse go than the inner?"

If this question is asked, in nearly every case the immediate reply is that it depends on the size of the track. It is somewhat paradoxical that the distance is $8 \pi$, or a little more than $25 \mathrm{ft}$., is actually independent both of the size and of the shape of the race track, provided that there is no reversal of curvature.

This problem is stated in a more formal manner in Williamson's "Integral Calculus," namely, if two curves have the same evolute the difference of their lengths is $4 \pi \mathrm{D}$, where $\mathrm{D}$ is the distance between the curves.

A. S. E.

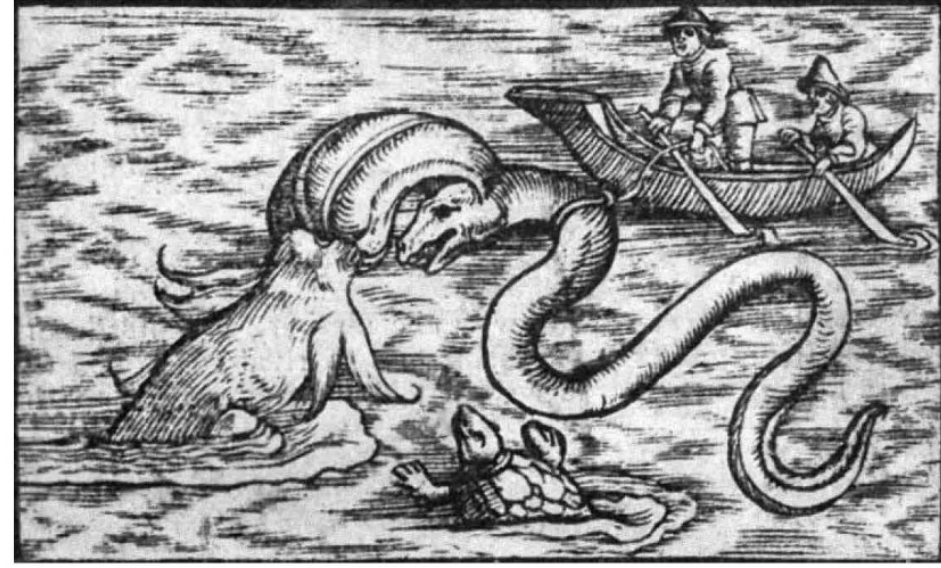

FIG. 2. -The Remora or "Reversus" as described by Christopher Columbus. (After Conrad

\section{A Mistaken Wasy.}

THE mistake made by the cabbage butterfly referred to in NATURE of May 20, appears to be made by other insects.

Quite recently (last week in April) whilst having lunch in a sunny room decorated with a light-coloured paper with a floral design of pink roses in full bloom, a large wasp entered and became very agitated; observing it for some little time, I noticed it alight every moment or so in the centre of one of the roses, remain a moment, then off again to another; it appeared to be getting very angry as it went from rose to rose, which it kept on doing during the time I was in the room--twenty minutes or so.

W. A. GunN.

Corporation Museum and Art Gallery, Dock Street, Newport, Mon., May 22. on the day following [May, r494] the Admiral being very desirous to find someone from whom he might obtain information, there came a canoe to hunt for fish :-for they call it hunting, and they hunt for one fish with another. They have fishes of a certain kind which they hold by a line fastened to their tails, and which are like the conger-eels in shape; and have a large mouth armed with suckers, like the cuttle-fish. They are very fierce, like our ferrets, and when they are thrown into the water, they go to fasten themselves upon some of the fishes there, and sooner die than let go their hold, till they are drawn out of the water. The fish is very light, and as soon as he has taken hold, the Indians draw him by the long cord tied to his tail, and immediately throw him into the water again; and in this way, they take one every time. As these hunters were at a distance from the caravel, the Admiral sent his armed boats to them, contriving it so that they should not escape to land. As the boats came up to them, these hunters called out to the men, as unconcernedly as if they had known them all their lives, to stop, because one of the fishes had fastened upon a large turtle, and they must wait till they had got it into the canoe.

"This our men did, and afterwards they took the canoe, and those in it, together with four turtles,

\section{THE PENGUINERY RE-VISITED. 1}

' $\Gamma H E$ author's fascinating popular account of the 1 social life of the Adélie Penguin (Pygoscelis adeliae) has been already reviewed in these columns, but the subject is of such great interest and Dr. Levick is such a consummate observer that we make no apology for turning to this second and more formal publication in the hope of adding to the completeness of the picture previously presented.

Apart from the observations made by the late Dr. Edward A. Wilson, which may be accepted, we are told, as "entirely correct," previous descriptions of the life of the Adélie Penguins have failed to do justice to these wonderful birds. About the middle of October they appear in ones and twos on the beach at Cape Adare, and by the end of the month there may be three-quarters

1 British Museum (Natural History). British Antarctic (Terra Noża Expedition, r9ro. Natural -History Report. Zoology. Vol. i., No, 2. "Natural History of the Adelie Penguin. By Stafisurgeon. Murray History), and Longmans, Green, and Co., Igis.) Price 5 s. No. 2378 , VOL. 95] 